\title{
Effects of the Covid-19 pandemic on brain and behavior
}

\author{
Tayfun UZBAY 1, 2 * (D) \\ 1 Department of Medical Pharmacology, Faculty of Medicine, Üsküdar University, İstanbul, Turkey. \\ 2 Neuropsychopharmacology Application and Research Center (NPARC), Üsküdar University, İstanbul, Turkey. \\ * Corresponding Author. E-mail: uzbayt@yahoo.com (T.U.); Tel. +90-216-400 2222.
}

Received: 09 July 2021/ Revised: 28 July 2021 / Accepted: 28 July 2021

\begin{abstract}
The Covid-19 viral infection, which was first detected in Wuhan, China at the end of 2019, spread rapidly around the world and turned into a major pandemic. At the time this article was written, Covid-19 has infected more than 250 million people worldwide, causing close to 5 million deaths. In addition to the fact that Covid-19 is a lytic infection, its easy spread through the respiratory tract required a social isolation that people were not accustomed in the pandemic period. Social isolation and economic losses caused significant social and psychological problems in society. On the other hand, Covid-19 also has direct effects on the central nervous system (CNS), and these effects may be responsible for some serious early or late neuropsychic disorders. In addition, acute symptoms of infection involved in respiratory system failure and cytokine storm, and vaccination activities were discussed detailed. Although neurological problems such as seizure, encephalitis, anosmia, dysgeusia, stroke and delirium are discussed to a certain extent, current data on psychological and/or psychiatric problems due to pandemic itself or the virus are remaining limited. In this review article, it is aimed to evaluate the effects of Covid-19 on brain and mental health in the light of current data. In addition, the literature on neuropsychiatric side effects of vaccines approved for emergency use was also reviewed.
\end{abstract}

KEYWORDS: Adverse effects; behavior; brain; central nervous system; Covid-19; neuropsychiatric effects; SARS-

CoV-2; vaccine.

\section{HISTORICAL BACKGROUND AND INTRODUCTION}

Pandemic is a word of Greek origin. It is a combination of the words "Pan" meaning all and "demos" meaning people. The word pandemic is an important public health term and is used to describe the rapid spread of an infectious disease to large numbers of people in each population in a short period of time. Throughout human history, many pandemics have emerged that have caused the death of many people and have affected the economy and the political sense of balance of the world, as well as public health [1]. Since the last century, especially influenza virus pandemics have emerged at certain intervals, causing problems. The world has experienced many viral pandemics between 1918 and 2012, beginning with the Spanish Flu. Except for the Spanish Flu, although they did not cause huge mass deaths, they had negative effects on public health and the economy. The year, origin, duration, and number of deaths caused by recent viral pandemics are shown in Table $1[1,2]$.

After SARS-CoV and MERS-CoV, we encountered a new pandemic in late 2019 that started in China (Wuhan city) and spread all over the world. This new virus, called SARS-CoV-2, belongs to the genus Betacoronavirus and subgenus Sarbecovirus of coronaviruses. These types of viruses cause severe acute respiratory syndrome (SARS) [2]. Thus, Covid-19 disease caused by the SARS-CoV-2 found out a major coronavirus epidemic with fast spread and deadly symptoms. It infected more than 250 million people worldwide and caused nearly 5 million dead as October 2021.

Covid-19 is a zoonotic disease and has transmitted from infected animals (ie. Bats and pangolin) to humans. It has approximately $80 \%$ sequence homology with SARS-CoV. However, genome studies showed that Covid-19 is almost $88 \%$ genetically similar to bats SARS-like coronavirus and genetically distant from the SARS and MERS viruses. Now it is contagious from human-to-human via respiratory droplets [3-5]. Coronaviruses are viruses with the largest RNA genome, whose genome consists of single-stranded RNA. SARS-CoV2, a novel form of coronaviruses, is ellipsoidal in shape and has a characteristic crown-shaped appearance. Spike proteins give the characteristic appearance to the virus and the copy number of spike proteins is 10-times higher than the influenza virus. Spikes can turn along the stalk freely. Virus's RNA is

How to cite this article: Uzbay T. Effects of the Covid-19 pandemic on brain and behavior. J Res Pharm. 2021; 25(6): $785-798$. 
packed together with ribonucleoproteins in the lumen (Figure 1). The genome encodes 16 non-structural proteins concerning viral replication and transcription such as RNA-dependent RNA polymerase and various structural proteins such as the spike surface glycoprotein, nucleocapsid protein, and envelope and matrix proteins [2].

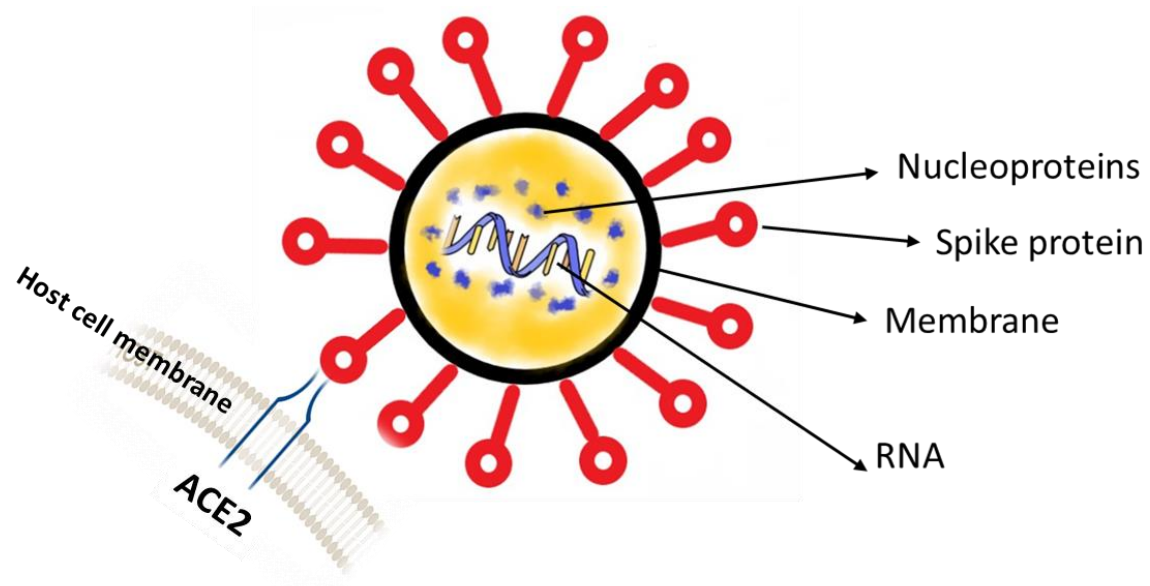

Figure 1. Typical scheme of SARS-CoV-2 virion structure and connecting with host ACE2 receptor binding site (ACE: Angiotensin converting enzyme).

Like to SARS-CoV, SARS-CoV-2 utilizes angiotensin 2 receptor binding site (ACE2) localized in the membrane of host for entry to the cell (Figure 1). ACE-2 receptors located on numerous distinct human cells. Thus, in some cases, SARS-CoV-2 causes a multisystemic disease called Covid-19 with high mortality rates. It is primarily targeted to the respiratory system and produce fatal symptoms in lungs such as acute respiratory distress syndrome (ARDS) following cytokine storm and pneumonia. In addition, it invades to the gastrointestinal (GIS) system, urinary system, skin, and central nervous system (CNS) and causes some other severe symptoms [6]. Unfortunately, we do not have any effective antiviral drug against coronavirus infections, including Covid-19, yet. Although some drugs such as lopinavir, ritonavir, favipiravir, chloroquine and hydroxychloroquine used in the treatment help to alleviate symptoms in some patients, their effects are controversial [7]. Wearing masks, social isolation and hygiene provide effective protection. Although vaccines that have been approved for emergency use give us a big confidence [8,9], it seems that it will take some more time for the pandemic to vanish completely.

There is a rapid flow of information to the literature regarding Covid-19, and a huge amount of knowledge has been accumulated in a short time. The cardiovascular, gastrointestinal and hematological effects of the disease, especially the respiratory system, were evaluated with detailed meta-analysis. The virus can also enter the CNS and causes some serious symptoms. Although there are some evaluations related to the neurological effects of the virus, the literature on its psychological and psychiatric effects is more limited. The aim of this review is to provide information to the reader by focusing on the effects of Covid-19 on the CNS, by evaluating the current literature related to its early and late effects.

\section{COVID-19 AND CNS}

\subsection{Routes and mechanisms of CNS involvement by COVID-19}

Numerous viruses may enter CNS by several routes involving the vasculature, the olfactory and trigeminal nerves, the cerebrospinal fluid, and the lymphatic system. Coronaviruses have also neurotropic and neuroinvasive capabilities in humans [10,11]. SARS-CoV-2 and other coronaviruses can enter the CNS and may cause inflammation and demyelization during infection [12,13]. Furthermore, existence of a brainlung-brain axes that responsible for brain injury and neurocognitive dysfunction during lung damage has described [14]. CNS involvement of Covid-19 may worsen the respiratory signs [15]. Recent several reports also indicated that various neurological symptoms may appear in Covid-19 and other coronavirus infections [15-18] and confirms that the virus has passed to the CNS. In addition, SARS-CoV-2 RNA was detected in the cerebrospinal fluid sample of patients with Covid-19 [19,20]. Although the underlying neurotropic mechanisms have not been fully determined yet, the mechanisms previously demonstrated for SARS-CoV and other viruses may also apply to explain. 
Table 1. Viral pandemics in the world in the last century.

\begin{tabular}{|c|c|c|c|c|}
\hline $\begin{array}{l}\text { Name of } \\
\text { disease }\end{array}$ & $\begin{array}{l}\text { Start and } \\
\text { End Year }\end{array}$ & $\begin{array}{l}\text { Region of } \\
\text { Origin }\end{array}$ & Virus & $\begin{array}{l}\text { Death } \\
\text { (estimate) }\end{array}$ \\
\hline $\begin{array}{l}\text { Spanish } \\
\text { Flu }\end{array}$ & $1918-1920$ & Europa & $\begin{array}{l}\text { Subtype } \\
\text { H1N1 }\end{array}$ & $\begin{array}{l}40-100 \\
\text { million }\end{array}$ \\
\hline Asian Flu & $1957-1958$ & China & $\begin{array}{l}\text { Subtype } \\
\text { H2N2 }\end{array}$ & 1 million \\
\hline $\begin{array}{l}\text { Hong } \\
\text { Kong Flu }\end{array}$ & $1968-1970$ & $\begin{array}{l}\text { Hong } \\
\text { Kong }\end{array}$ & $\begin{array}{l}\text { Subtype } \\
\text { H3N2 }\end{array}$ & $\begin{array}{c}1-4 \\
\text { million }\end{array}$ \\
\hline $\begin{array}{l}\text { Russian } \\
\text { Flu }\end{array}$ & 1977-1977 & Russia & $\begin{array}{l}\text { Subtype } \\
\text { H1N1 }\end{array}$ & 250.000 \\
\hline SARSa & 2002-2004 & China & $\begin{array}{l}\text { SARS- } \\
\text { CoV-1 }\end{array}$ & 774 \\
\hline MERSb & $\begin{array}{l}2012- \\
\text { present }\end{array}$ & $\begin{array}{l}\text { Saudi } \\
\text { Arabia }\end{array}$ & MER-Cov & 862 \\
\hline Covid-19 & $\begin{array}{l}2019- \\
\text { present }\end{array}$ & China & $\begin{array}{l}\text { SARS- } \\
\text { CoV-2 }\end{array}$ & $\begin{array}{l}\text { nearly } 5 \\
\text { million }\end{array}$ \\
\hline
\end{tabular}

Like SARS-CoV, SARS-CoV-2 uses the angiotensin-converting enzyme 2 (ACE2) receptor to enter human cells (Figure 1). Abundant ACE2-expressing regions are also found in neurons and glial cells [15,20,21]. The entry of SARS-CoV-2 into the CNS and its effects may be in the form of direct hematogenous or neuronal retrograde spread. The virus can also affect the CNS indirectly. On hematogenous entry, the virus can infect endothelial cells of the blood brain barrier or infect leukocytes to spread to the CNS [11,22,23]. The virus can also bind to ACE2 receptors expressed in the capillary endothelium of the blood brain barrier to gain access to the CNS [24]. As a second major route of entry into the CNS, it can use axonal transport systems to infect peripheral neurons for entering the CNS $[11,22,23]$. This mechanism may be related to the entry of SARS-CoV2 into the CNS via the cranial nerve.

ACE2 binding sites are widely expressed in epithelial cells of the oral mucosa [25]. Furthermore, the olfactory nerve serves as a shortcut for many viruses to enter the CNS. Dendrites originated from olfactory neurons project into the nasal cavity and extend their axons via the cribriform plate into the olfactory bulb [26]. Positive test results on nasopharyngeal swabs of many patients confirmed that the main routes of spread of SARS-CoV-2 were nasal and respiratory tract $[27,28]$. In addition, studies in transgenic mice that mimic human ACE2 receptors have found that SARS-CoV-2 enters the brain mainly through the olfactory bulb. Then, it rapidly reaches other parts of the brain via transneuronal spread [29]. This information may also partially explain the mechanism of cranial nervous system symptoms in Covid-19.

Covid-19 can also affect the CNS indirectly [30]. Intracranial cytokine storms and hypoxia that occur during infection without a direct viral invasion may damage the blood brain barrier, facilitating virus transmission and causing the development of acute severe neurological symptoms [31,32]. The virus that replicates in the lungs can then travel retrogradely between neuronal synapses to infiltrate the brain stem. This approach also explains how Covid-19 causes cardiovascular and pulmonary complications from brainstem [33].

\subsection{Neurological effects of COVID-19 infection}

Once Covid-19 effects the CNS, it can cause many neurological complications. Some of these progress as simple symptoms and are temporary. In some cases, severe and permanent disorders may occur. Some neurological disorders may appear later and lead to permanent problems.

Covid-19 also promotes the development of Guillain-Barré syndrome, a form of paralysis in which the body's immune system attacks the nerves [33].

In addition to the acute effects, there may be chronic neurological consequences of Covid-19 infection. Although a direct link between Covid-19 and demyelinating disease such as multiple sclerosis has not yet been established, there are results that imply a relationship between human coronaviruses and multiple sclerosis (MS). MS mouse models also developed acute encephalomyelitis and a chronic demyelinating condition when infected with the coronavirus strain [34]. The diagnosis of Covid-19 infection should be kept 
in mind when patients show specific or nonspecific neurological symptoms during the pandemic period. Much more attention should be paid to the risk of neurological involvement in patients with Covid-19.

\subsubsection{Chemosensory impairments}

Some chemosensory symptoms such as anosmia and dysgeusia were reported at remarkable rates in individuals who tested positive for Covid-19. Considering the role of the nasal cavity and olfactory bulb in the transmission of similar viruses to the CNS [26], this is not a surprise finding, and it also confirms that Covid19 causes a failure in the chemosensory system. These symptoms typically appear at the onset of the disease and growing evidence indicate that they are related to Covid-19. Thus, it has been suggested that the taste and smell changes can be considered as an early warning for the diagnosis of the disease [35,36]. Indeed, olfactory and/or gustatory dysfunction are the most common neurological manifestations reported in patients with Covid-19. The pooled prevalence for olfactory and gustatory dysfunctions was found as approximately $53 \%$ and $44 \%$, respectively [37,38]. Recently, Mazzoli et al. [39] also reported hyposmia/anosmia in $45 \%$ of 51 Covid-19 patients. More than $80 \%$ loss of smell and taste has been reported in multicenter studies evaluating more subjects [36,40].

The olfactory and gustatory systems, alongside with parts of the somatosensory system that communicates chemesthesis, are distinct sensory systems with separate peripheral and central neuronal mechanisms [41,42]. Smell, taste, and chemesthesis are often mistaken, because they appear a single experience of flavor during eating, and patients frequently report a loss of taste when in fact they are experiencing a loss of retronasal olfaction. By this time, the influence of Covid-19 on each of these three chemosensory modalities remains poorly understood. The multimodal impact of Covid-19 and lack of perceived nasal obstruction suggest that the infection may disturb sensory-neural processes [43].

\subsubsection{Encephalopathy and ischemic stroke}

Encephalopathy is a pathological process in the brain that typically extends over hours to days can demonstrate as changed personality, behavior, cognition, or consciousness. It includes some serious clinical signs such as delirium and seizures. Encephalitis is also an inflammation of the brain parenchyma, usually triggered by an infection of the body's immune system [44,45]. Encephalopathy or encephalitis has been observed in some Covid-19 patients, especially those with severe illness [44,46]. In a meta-analysis study, the incidence of encephalopathy and encephalitis among 33 patients who have neurological symptoms was reported as $3 \%$ and $1 \%$, respectively [47].

We do not know the mechanism of encephalopathy in patients with Covid-19 yet. According to clinical observations, encephalopathy was more common in those who had a severe illness, comorbid other chronic diseases, organ failure as a result of hypoxia, renal and hepatic dysfunction, and those with high systemic inflammation markers [3]. The entrance of SARS-CoV-2 to CNS activates glial cells, increases tumor necrosis factor-alpha (TNF-a) together with IL-6, IL-12, IL-15 and causes a severe inflammation. The virus can also infiltrate the CNS by binding to ACE2 receptors on endothelial cells across the blood-brain barrier, or it can directly disrupt the blood-brain barrier, leading to acute necrotizing encephalopathy. This may also be the cause of hypoxic ischemic encephalopathy, which develops after disease onset in approximately $20 \%$ of hospitalized patients [33]. The presence of Covid-19, which can also induce encephalitis, has been demonstrated in the cerebrospinal fluid [48].

Ischemic stroke may occur, especially in hospitalized patients who develop coagulopathy and coagulopathy may related to higher mortality. The coagulopathy observed in Covid-19, together with the cytokine storm, may predispose patients to both thrombotic and hemorrhagic cerebrovascular events [49]. Besides inflammation and hypoxia, hypercoagulability was associated with an increased risk of stroke [50]. In various clinical evaluations, the frequency of stroke in patients was found to be around $1-2 \%[38,44,51]$. The stroke cases were older, had more comorbidities involving hypertension, diabetes, and prior stroke history. They also had elevated inflammatory markers such as c-reactive protein [3].

Other cerebrovascular problems such as cerebral hemorrhage have also been observed in Covid-19. A meta-analysis found that the severity of Covid-19 was 2.5-fold higher in patients with a history of cerebrovascular disease [52].

\subsubsection{Epileptic seizures}

Myoclonus [53,54], seizures [55,56], status epilepticus [57,58] and acute encephalopathic epilepsy [59] were reported in patient with Covid-19. Most of these seizures were not associated with a previous history of epileptic disorder. However, it can be thought that the neurological damages caused by Covid-19 may increase 
the susceptibility to epilepsy. More time is needed to understand whether the seizures observed for the first time in Covid-19 patients can be permanent. It is also unclear whether a previous Covid-19 will lead to a later epileptic picture in susceptible individuals.

Cheli et al. [60] suggested that there was a decrease in the outpatient or clinical applications of epilepsy patients during quarantine periods, but there was no significant change in the number of EEG records and the number of first-diagnosed epileptic patients compared to the pre-pandemic period.

\subsubsection{Headache and migraine}

Headache is one of the most common symptoms observed in patients diagnosed with Covid-19. While the headache is mild or moderate in the beginning of the disease, severe headaches may occur in some cases [51,61]. However, in an evaluation of 59254 cases based on a meta-analysis of 61 studies, the frequency of headache was found to be $12 \%$ [62]. In another retrospective case-control study, the frequency of headache was found to be 13\% [63]. Extensive studies rank headache in fifth place after fever, cough, myalgia, and dyspnea [62]. The results of two recently published studies also indicate that Covid-19 increases the frequency of migraine attacks $[64,65]$. Headache and migraine-like symptoms observed in Covid-19 may be related to the effects of the virus on the cerebrovascular system.

\subsubsection{Other neurological symptoms}

Neuroleptic malignant syndrome [66], post-infectious acute transverse myelitis [67], neuromuscular dysfunction or demyelinating process [61,68], inflammatory neuropathy [51], Guillain-Barre syndrome [69] and facial palsy [70] were also observed and reported in patients with Covid-19 as other important neurological findings.

\subsection{Behavioral and psychiatric effects of COVID-19 infection}

The most stressed issue in Covid-19 patients was the serious symptoms that cause morbidity and mortality and that occur in the acute phase of the disease, concerning the respiratory, cardiovascular and nervous systems. Studies evaluating the effects of Covid-19 on mental state and mood apart from neurological symptoms are extremely limited. One reason for this is that in the context of the pandemic, attention is more focused on acute fatal effects of the disease. Another reason is that problems such as anxiety, depression, and post-traumatic stress disorder, which are especially related to mood, may arise in the periods after the illness. In addition, the mood problems do not concern only Covid-19 patients but also non-Covid-19 individuals. The social isolation, fear of death, economic problems and radical changes in lifestyle brought about by the pandemic seriously threaten the mental health of those who do not have the disease. Significant increases are expected in the incidence of psychiatric disorders in the post-pandemic period, and related measures should be taken now.

\subsubsection{Post-COVID-19 syndrome}

Some of the patients with mild/moderate Covid-19 exhibited post-or long-Covid-19 syndrome symptoms lasting 12 weeks or longer. The most common symptoms in patients suffering from post-Covid-19 syndrome are fatigue, dyspnea, anxiety, depression and impaired attention, concentration, memory, and sleep. The underlying biological mechanisms are unknown, but abnormal or excessive autoimmune and inflammatory response may play an important role. Limbic brain formations such as hippocampus and basal ganglia include more enzymes that are regarding inflammatory responses than other areas. Consequently, there is an increased risk of emerging deficits in neurocognitive activities like emotion, attention, and memory. Patients with chronic hypoxia as in Covid-19 related to pulmonary diseases, may have poor performance on attention and executive functions [71].

The hippocampus, concerning learning and memory processes, is especially sensitive to neuroinflammation. Inflammatory cytokines can impair hippocampal long-term potentiation and influence synaptic plasticity and memory formation negatively [72]. As a matter of fact, disturbances in mood and cognitive functions observed in prolonged Covid-19 or post-Covid-19 may be related to the effects of the virus on the limbic system and neuroinflammation in this brain region. Emotional distress such as anxiety, depression and insomnia could also support to subjective cognitive complaints [71]. Previously, it has been suggested that neuroinflammation caused by non-neurotropic and neurotropic influenza viruses induced long-lasting impairments in hippocampal neuronal morphology and cognitive functions in mice [72]. It has been suggested that major depression, severe anxiety symptoms, insomnia and post-traumatic stress disorder appearing in post-Covid-19 may also increase the risk of suicide [73]. 
The incidence of Post Covid-19 syndrome varies between 10-65\% in case groups [74,75]. Although fatigue and neurocognitive complaints dominate, clinical manifestations are varied, fluctuating and variable. There is no defined consensus on the post-Covid-19 syndrome and the diagnostic criteria have not been adequately psychometrically evaluated. However, the results of a comprehensive meta-analysis, which was published recently and evaluated 218 articles, indicate that approximately $20 \%$ of patients experience lungrelated problems. Extreme fatigue is prominent with a frequency of over $55 \%$. In the articles evaluated, anxiety, depression and post-traumatic stress disorder were reported at varying rates such as $20-46 \%, 18-48 \%$ and $25 \%$, respectively in post-Covid term [76]. These observations indicate that patients should be monitored in terms of mental health as well as lung problems and muscle pain in the post-Covid period.

\subsubsection{Delirium and bizarre behaviors}

Impairment of consciousness and delirium have been frequently reported in patients with Covid-19. Some of these problems occur as a result of encephalopathy and neurological problems such as encephalitis [51]. In addition, long-term hospital care and social isolation of the elderly people increase the incidence of delirium. In clinical evaluations, the incidence of delirium in Covid-19 cases was reported to be between 10$28 \%$ [77,78]. In the evaluation of a group of 817 patients who applied to the American emergency services due to Covid-19, it was determined that 37 patients (16\%) exhibited delirium as the primary symptom [77]. Delirium is a symptom that can result in death and should be taken into consideration especially in the elderly and in long-term hospitalization. If considered, it is a preventable symptom with appropriate treatment.

A 53-year Covid-19 infected old man exhibited bizarre behavior was reported [79]. Besides, cough, dyspnea, fewer, myalgia and headache, he exhibited dysarthria and some bizarre behaviors such as getting naked in front of everyone and urinate in the room. CT and MRI results were normal, and encephalopathy cannot be detected. He did not have any medical history like this. When the patient recovered after Covid-19 treatment, these symptoms disappeared like other Covid-19 symptoms. After Covid-19 treatment, symptoms of infection as well as dysarthria and bizarre behaviors improved. Although this case implies that Covid-19 may be associated with bizarre behaviors, more cases are needed for evidence.

\subsubsection{Mental problems due to chronic stress and social isolation}

During the Covid-19 period, considerable increases were observed in the frequency of depression, various anxiety disorders, sleep abnormalities and suicide attempts in the population [80,81]. These mental problems occur not only in those who test positive for Covid-19, but also in those who have no history of Covid-19. Social isolation-induced limitations, economic troubles and fear of death have led to chronic stress as in other similar social and psychologic problems. Chronic stress causes continuous cortisol release by stimulating the hypothalamo-pituitary axis in both experimental animals and human $[82,83]$. It is one of the major reasons of anxiety, depression, sleep disorders and post-traumatic stress disorder. These diseases increase the risk of suicide as well.

The pandemic has also markedly increased the tendency to abuse alcohol and other addictive drugs. In this period, an increase was observed in the number of applications to emergency services due to problems related to excessive alcohol consumption and other addictive substance use [84-86]. Alcohol and substance abuse can produce a serious public health problem after the pandemic and should be monitored carefully. Addictive substance use and disorders such as anxiety and depression can often be comorbid. They can potentiate each other or be the cause of each other. We need more studies in this area so that we can more reasonably assess the extent of alcohol and other addictive substance use during the pandemic.

Covid-19 is also triggering schizophrenia symptoms and causing suicidal behavior in non-Covid-19 positive individuals. The results of a multicenter study conducted in Europe during the period of intense Covid-19 restrictions confirmed this observation [87]. There have also been reports of some suicide attempts who were positive for Covid-19 and had no previous psychiatric history [88,89]. In addition, it has been suggested that suicide attempts in population increased as related to economic losses or reduced social ties during the Covid-19 outbreak [90].

Physicians must be alert of the possibility of depression, anxiety, fatigue, post-traumatic stress disorder, psychotic signs, suicidal ideas, and other rare neuropsychiatric syndromes in the outcome.

Another important problem is the condition of children who are confined to their homes during periods of lockdown and strict isolation. Especially in children and adolescents with diseases such as attention deficit hyperactivity disorder (ADHD) and autism, fluctuations and increases in their symptoms emerged in this process. This statement also negatively affected the mood of the parents and caregivers [91-93]. Sleep disturbances in children and adolescents with ADHD were also reported [94]. The best way to benefit autistic 
children caught up in drastic changes in their routine lifestyle is to invest in a strong support system for their parents. It was very important to support children suffering from neurodevelopmental problems and their parents and caregivers during lockdown periods. For this purpose, a remote serve system called telehealth or telemedicine involved in telephone calls or videoconference has been established. The system is mostly effectively used in cases with autism and ADHD [95].

A sedentary life style that includes social isolation and inactivity or immobility are very bad for brain health and mood. This situation is a more serious risk for elder individuals. It will aggravate dementias such as Alzheimer's, and depression, and increase susceptibility to these diseases [96,97]. Mental health of the elderly population has also been negatively affected by the lockdown periods during Covid-19 pandemic. It has been reported that the behavioral, cognitive and psychological symptoms of patients with dementia and Alzheimer's have worsened [98-100]. On the other hand, caregivers of elderly patients faced an increased stress load during this period. This situation both affected the mental health of the caregivers negatively and caused the quality of the care they provided to decrease and the condition of the patients to worsen accordingly $[101,102]$. Remote telemedicine applications have helped especially patients with dementia and caregivers to some extent. In addition, it reduces emergency department requirement of elderly individuals [103,104].

\section{VACCINES AND CNS}

Vaccine is the most important discovery of preventive medicine. The development of vaccines has been extremely effective in preventing lethal infections and reduction their global spread. In this way, many fatal infections such as smallpox, were eradicated [105]. After Covid-19 turned into a pandemic, the standard stages for vaccine development were unprecedentedly accelerated and many vaccines were developed within a year. Some of these vaccines have received emergency approval following phase studies. Information on typically used vaccines that have received emergency approval are summarized in Table 2. Vaccination activities continue at full speed with these vaccines in America, Europe, Russia, Israel, China, Japan, South Korea, Turkey and many other countries. In developed countries, more than half of the population has already been vaccinated.

Table 2. Vaccines approved for emergency use.

\begin{tabular}{llllll}
\hline Name & Country & Mechanism & Storage & Efficacy (\%) & CA $^{\mathbf{b}}$ \\
\hline $\begin{array}{l}\text { Pfizer \& } \\
\text { Biontech }\end{array}$ & USA \& Germany & mRNA & $-20^{\circ} \mathrm{C}$ & 95 & 63 \\
$\begin{array}{l}\text { Moderna } \\
\text { Sputnik V }\end{array}$ & USA & Russia & $-20^{\circ} \mathrm{C}$ & 95 & 27 \\
$\begin{array}{l}\text { Sinovac } \\
\text { Johnson \& }\end{array}$ & China & Vector & $+4{ }^{\circ} \mathrm{C}$ & 92 & 9 \\
Johnson & Inactivated & $+4{ }^{\circ} \mathrm{C}$ & $50-78$ & 6 \\
$\begin{array}{l}\text { Oxford \& } \\
\text { Astra Zeneca }\end{array}$ & UK \& Sweden & Vector & $+4{ }^{\circ} \mathrm{C}$ & 66 & 1 \\
$\begin{array}{l}\text { a Modified from Burges et al., 2021 [9]. } \\
\text { b Country number given approval. }\end{array}$ & & & & \\
\end{tabular}

The protection of vaccines in spreadable infections is clear and indisputable and the current vaccines have a very high level of protection [106]. However, emergency approvals raise the question of the safety of vaccines in terms of side effects and adverse reactions. Before Covid-19, there were live attenuated, inactivated, toxoid, subunit, recombinant, polysaccharide and conjugated vaccine platforms. With Covid-19, mRNA vaccines began to be used as a new platform $[107,108]$. Although the efforts to develop mRNA vaccines date back to the past, they were first time used in humans during Covid-19 pandemic. Although mRNA vaccines are the first vaccines to be approved by Food and Drug Administration (FDA) and European Medicine Agency (EMA), have been applied in a very large population around the world and found to be safe in terms of side effect profile in some detailed reviews in the literature [106,109], more time is needed for the definitive safety of these vaccines. Due to the scope of this review, here the current literature regarding the side effects of current vaccines on the CNS has been evaluated.

According to a detailed evaluation [110], though rare, mild and severe neurological side effects have been occasionally reported after Covid-19 vaccination. Data from the mRNA vaccine clinical trials showed that 7 cases out of 37,000 vaccine recipients developed Bell's palsy. In the DNA-based Johnson \& Johnson 
vaccine trial, one patient each in the vaccinated and placebo group developed Guillain-Barre syndrome. According to the FDA Adverse Event Reporting System (FAERS), 9442 reports of adverse reactions to the vaccines have been submitted as of March 2, 2021. The most common neurological symptoms included dizziness, headache, pain, muscle spasms, myalgia and paresthesia, which are expected to occur as acute, transient effects of the vaccination. Rare cases of tremor, diplopia, tinnitus, dysphonia, seizures and reactivation of herpes zoster have been also reported. There were also cases of stroke $(n=17)$, Guillain Barre Syndrome $(n=32)$, facial palsy $(n=190)$, transverse myelitis $(n=9)$ and acute disseminated encephalomyelitis $(\mathrm{ADEM})(\mathrm{n}=6)$ in the databases. In a trial with the Sinovac and Sinopharm vaccines, $68 \%$ of participants reported post-vaccination headache and $60 \%$ had myalgia. Because deep venous thrombosis (DVT) is also a potential risk factor for ischemic stroke, individuals exhibiting thrombosis as a potential side effect of the vaccines should be take into consideration [110].

A case of new-onset refractory status epilepticus after injecting the first dose of the ChAdOx1 nCoV-19 (Oxford \& Astra Zeneca) vaccine has recently reported. The authors attribute the occurrence of this symptom to the vaccine due to the temporal relationship and the lack of risk factors for epilepsy in the patient [111]. This report contributes to the extremely limited literature on potential neurological side effects of viral vector vaccines. It also indicates that healthcare providers should be aware of the possibility of post-vaccination epilepsy. In addition, neurologic phantosmia detecting with positive magnetic resonance imaging radiographic findings has recently reported in a patient with documented absence of infection by Covid-19 virus or concomitant sinonasal disease following Pfizer-BioNtech vaccination [112].

Current neurologic adverse effects after the Covid-19 vaccinations are rare. Based on the existing evidence, though more neurological adverse effects were reported with the substantial worldwide vaccination, the causativeness is yet to be confirmed. As the vaccinated population increases, predictable more neurological events will be seen. The link between them and the vaccine association will need to be tested by comparing their incidence rate with epidemiological data preceding the pandemic [113].

\section{CONCLUSIONS}

Covid-19-mediated mental health complications and cerebrovascular conditions may cause a huge burden on healthcare communities in the future. Anxiety and stress like mental illnesses are the common outcomes of viral epidemics and pandemics. A large population of the world is prone to develop anxiety, depressive disorders, and other mental abnormalities. Mental symptoms ensued by the Covid-19 pandemic due to restricted social activities, restrictions culminating into stress and anxiety should not be ignored. Patients with underlying neurological diseases such as stroke should be given proper attention. To cope with the psychological consequences of the outbreak, clinical psychologists and psychiatrists should come forward and provide their services that could help the medical staff and clinical workers to work efficiently and the general public to stay healthy [114].

Early data indicate that vaccines will be effective in ending the pandemic. However, the use of vaccines faster than usual and especially debates on their long-term side effects cause hesitations and decrease in participation in the vaccine program in the population. Although the protective effects of the current vaccines are quite clear, there is a possibility of some unpredictable side effects existing in the long term. More time is needed to clarify such issues. However, there is also a possibility that some permanent neuropsychiatric diseases may occur after past pandemic terms. In addition, being infected with various microorganisms and viral infections may lead to brain dysfunction and neuropsychiatric diseases such as schizophrenia, depression, and bipolar disorder [115-117]. Although it is unclear what kind of problems the Covid-19 infection will cause in the long run, the risk here is quite high compared to the vaccine. Therefore, getting involved in the vaccination program and avoiding Covid-19 seems to be the best option.

The Covid-19 outbreak will eventually end, but it could cost thousands of lives and millions with severe mental problems. Dealing properly with this critical situation, the top of the government's agenda should be the development of a huge network of clinical psychologists and psychiatrists to assist the public, doctors, medical assistants, technicians, and nurses working at the front line. 
Acknowledgements: Author would like to thank Dr. Ayşe Özçetin Şenöz for her kind help.

Author contributions: Concept - T.U.; Design - T.U.; Supervision - T.U.; Resources - T.U.; Materials - T.U.; Data Collection and/or Processing - T.U.; Analysis and/or Interpretation - T.U.; Literature Search - T.U.; Writing - T.U.; Critical Reviews - T.U.

Conflict of interest statement: The author declared no conflict of interest in the manuscript.

\section{REFERENCES}

[1] Nafees MU, Ullah SA, Khalil AA, Roohullah M, Muhammad A. Pandemics of influenza viruses and coronaviruses; past and present. Bull Environ Pharmacol Life Sci. 2020; 9: 167-171.

[2] Khan M, Adil SF, Alkhathlan H, Tahir MN, Saif S, Khan M, Khan ST. Covid-19: A global challenge with old history, epidemiology and progress so far. Molecules. 2021; 26: 39. [CrossRef]

[3] Koralnik IJ, Tyler KL. Covid-19: a global threat to the nervous system. Ann Neurol. 2020; 88: 1-11. [CrossRef]

[4] Ren Li, Wang Y, Wu Z, Xiang ZC, Guo Li, Xu T, Jiang YZ, Xiong Y, Li YJ, Li XW, Li H, Fan GH, Gu X-Y, Xiao Y, Gao H, Xu JY, Yang F, Wang XM, Wu C, Chen L, Liu YW, Liu B, Yang J, Wang XR, Dong J, Li L, Huang CL, Zhao JP, Hu Y, Cheng ZS, Liu LL, Qian ZH, Qin C, Jin Q, Cao B, Wang JW. Identification of a novel coronavirus causing severe pneumonia in human: a descriptive study. Chin Med J. 2020; 133: 1015-1024. [CrossRef]

[5] Lovato A, de Filippis C. Clinical presentation of COVID-19: A systematic review focusing on upper airway symptoms. Ear Nose Throat J. 2020; 99: 569-576. [CrossRef]

[6] Gavriatopoulou M, Korompoki E, Fotiou D, Ntanasis-Stathopoulos I, Psaltopoulou T, Kastritis E, Terpos E, Dimopoulos MA. Organ-specific manifestations of COVID-19 infection. Clin Exp Med. 2020; 20: 493-506. [CrossRef]

[7] Park YJ, Farooq J, Cho J, Sadanandan N, Cozene B, Gonzales-Portillo B, Saft M, Borlongan MC, Borlongan MC, Shytle RD, Willing AE, Garbuzova-Davis S, Sanberg PR, Borlongan CV. Fighting the war against Covid-19 via cell-based regenerative medicine: Lessons learned from 1918 Spanish Flu and other previous pandemics. Stem Cell Rev Rep. 2021; 17: 9-32. [CrossRef]

[8] Burgess HL, Braithwaite JJ, Singleton E, Young AM, Cooper MK. Covid-19: Race for a vaccine. HCA Healthcare J. 2020; 1: 463-474. [CrossRef]

[9] Burgess HL, Castelein C, Rubio A, Cooper MK. COVID-19: The vaccine race continues. HCA Healthcare J. 2021; 2: 81-91. [CrossRef]

[10] Desforges M, Le Coupanec A, Brison E, Meessen-Pinard M, Talbot PJ. Neuroinvasive and neurotropic human respiratory coronaviruses: potential neurovirulent agents in humans. Adv Exp Med Biol. 2014; 807: 75-96. [CrossRef]

[11] Desforges M, Le Coupanec A, Dubeau P, Bourgouin A, Lajoie L, Dubé M, Talbot PJ. Human coronaviruses and othe respiratory viruses: Underestimated opportunistic pathogens of the central nervous system? Viruses. 2019; $12: 14$. [CrossRef]

[12] Bohmwald K, Gálvez NMS, Ríos M, Kalergis AM. Neurologic alterations due to respiratory virus infections. Front Cell Neurosci. 2018; 12: 386. [CrossRef]

[13] Nuzzo D, Picone P. Potential neurological effects of severe Covid-19 infection. Neurosci Res. 2020; 158: 1-5. [CrossRef]

[14] Stevens RD, Puybasset L. The brain-lung-brain axis. Intensive Care Care Med. 2011; 37: 1054-1056. [CrossRef]

[15] Saleki K, Banazadeh M, Saghazadeh A, Rezai N. The involvement of the central nervous system in patients with Covid-19. Rev Neurosci. 2020; 31: 453-456. [CrossRef]

[16] Asadi-Pooya AA, Simani L. Central nervous system manifestations of Covid-19: A systematic review. J Neurol Sci. 2020; 413: 116832. [CrossRef]

[17] Katal S, Balakrishnan S, Gholamrezanezhad A. Neuroimaging and neurologic findings in Covid-19 and other coronavirus infections: A systematic review in 116 patients. J Neuroradiol. 2021; 48: 43-50. [CrossRef]

[18] Nazari S, Jafari AA, Mirmoeeni S, Sadeghian S, Heidari ME, Sadeghian S, Assarzadegan F, Puormand SM, Ebadi H, Fathi D, Dalvant S. Central nervous system manifestations in Covid-19 patients: A systematic review and metaanalysis. Brain Behav. 2021; 11(5): e02025. [CrossRef]

[19] Moriguchi T, Harii N, Goto J, Harada D, Sugawara H, Takamino J, Ueno M, Sakata H, Kondo K, Myose N, Nakao A, Takeda M, Haro H, Inoue O, Suzuki-Inoue K, Kubokawa K, Ogihara S, Sasaki T, Kinouchi H, Kojin H, Ito M, Onishi 
H, Shimizu T, Sasaki Y, Enomoto N, Ishihara H, Furuya S, Yamamoto T, Shimada S. A first case of meningitis/encephalitis associated with SARS-Coronavirus-2. Int J Infect Dis. 2020; 95: 55-58. [CrossRef]

[20] Zhou Z, Kang H, Li S, Zhao X. Understanding the neurotropic characteristics of SARS-CoV-2: from neurological manifestations of COVID-19 to potential neurotropic mechanisms. J Neurol. 2020; 267: 2179-2184. [CrossRef]

[21] Natoli S, Oliveira V, Calabresi P, Maia LF, Pisani A. Does SARS-Cov-2 invade the brain? Translational lessons from animal models. Eur J Neurol. 2020; 27: 1764-1773. [CrossRef]

[22] Desforges M, Le Coupanec A, Stodola JK, Meessen-Pinard M, Talbot PJ. Human coronaviruses: viral and cellular factors involved in neuroinvasiveness and neuropathogenesis. Virus Res. 2014; 194: 145-158. [CrossRef]

[23] Swanson PA 2nd, McGawern DB. Viral diseases of the central nervous system. Curr Opin Virol. 2015; 11: 44-54. [CrossRef]

[24] Baig AM, Khaleeq A, Ali U, Syeda H. Evidence of the COVID-19 virus targeting the CNS: Tissue distribution, hostvirus interaction, and proposed neurotropic mechanisms. ACS Chem Neurosci. 2020; 11: 995-998. [CrossRef]

[25] Xu H, Zhong L, Deng J, Peng J, Dan H, Zeng X, Li T, Chen Q. High expression of ACE2 receptor of 2019-nCoV on the epithelial cells of oral mucosa. Int J Oral Sci. 2020; 12(1): 8. [CrossRef]

[26] van Riel D, Verdijk R, Kuiken T. The olfactory nerve: a shortcut for influenza and other viral diseases into the central nervous system. J Pathol. 2015; 235: 277-287. [CrossRef]

[27] Wu P, Duan F, Luo C, Liu Q, Qu X, Liang L, Wu K. Characteristics of ocular findings of patients with coronavirus disease 2019 (COVID-19) in Hubei Province, China. JAMA Ophtalmol. 2020; 138: 575-578. [CrossRef]

[28] Wu Z, McGoogan JM. Characteristics of and important lessons from the Coronavirus disease 2019 (COVID-19) outbreak in China: Summary of a report of 72314 cases from the Chinese center for disease control and prevention. JAMA. 2020; 323: 1239-1242. [CrossRef]

[29] Netland J, Meyerholz DK, Moore S, Cassell M, Perlman S. Severe acute respiratory syndrome coronavirus infection causes neuronal death in the absence of encephalitis in mice transgenic for human ACE2. J Virol. 2008; 82: 7264-7275. [CrossRef]

[30] Wu Y, Xu X, Chen Z, Duan J, Hashimoto K, Yang L, Liu C, Yang C. Nervous system involvement after infection with COVID-19 and other coronaviruses. Brain Behav Immun. 2020; 87: 18-22. [CrossRef]

[31] Poyiadji N, Shahin G, Noujaim D, Stone M, Patel S, Griffith B. COVID-19-associated acute hemorrhagic necrotizing encephalopathy: Imaging features. Radiology. 2020; 296: E119-E120. [CrossRef]

[32] Zhao H, Shen D, Zhou H, Liu J, Chen S. Guillain-Barré syndrome associated with SARS-CoV-2 infection: causality or coincidence? Lancet Neurol. 2020; 19: 383-384. [CrossRef]

[33] Bridwell R, Long B, Gottlieb M. Neurologic complications of Covid-19. Am J Emerg Med. 2020; 38(7): 1549.e3-1549.e7. [CrossRef]

[34] Montalvan V, Lee J, Bueso T, De Toledo J, Rivas K. Neurological manifestations of COVID-19 and other coronavirus infections: A systematic review. Clin Neurol Neurosurg. 2020; 194: 105921. [CrossRef]

[35] Pierron D, Pereda-Loth V, Mantel M, Moranges M, Bignon E, Alva O, Kabous J, Heiske M, Pacalon J, David R, Dinnella C, Spinelli S, Monteleone E, Farruggia MC, Cooper KW, Sell EA, Thomas-Danguin T, Bakke AJ, Parma V, Hayes JE, Letellier T, Ferdenzi C, Golebiowski J, Bensafi M. Smell and taste changes are early indicators of the COVID-19 pandemic and political decision effectiveness. Nat Commun. 2020; 11: 5152. [CrossRef]

[36] Zahra SA, Iddawela S, Pillai K, Choudhury RY, Harky A. Can symptoms of anosmia, dysgeusia be diagnostic for Covid-19. Brain Behav. 2020; 10(11): e01839. [CrossRef]

[37] Tong JY, Wong A, Zhu D, Fastenberg JH, Tham T. The prevalence of olfactory and gustatory dysfunction in COVID19 patients: A systematic review and meta-analysis. Otolaryngol Head Neck Surg. 2020; 163: 3-11. [CrossRef]

[38] Leung TYM, Chan AYL, Chan EW, Chan VKY, Chui CSL, Cowling BJ, Gao L, G MQ, Hung IFN, Ip MSM, Ip P, Lau K, Lau CS, Lau LKW, Leung WK, Li X, Luo H, Man KKC, Ng VWS, Siu CW, Wan EYF, Wing YK, Wong CSM, Wong KHT, Wong ICK. Short- and potential long-term adverse health outcomes of Covid-19: A rapid review. Emerg Microbes Infect. 2020; 9: 2190-2199. [CrossRef]

[39] Mazzoli M, Molinari MA, Tondelli M, Giovanni G, Ricceri R, Ciolli L, Picchetto L, Meletti S. Olfactory function and viral recovery in Covid-19. Brain Behav. 2021; 11(3): e02006. [CrossRef]

[40] Lechien JR, Chiesa-Estomba CM, De Siati DR, Horoi M, Le Bon SD, Rodriguez A, Dequanter D, Blecic S, El Afia F, Distinguin L, Chekkoury-Idrissi Y, Hans S, Delgado IL, Calvo-Henriquez C, Lavigne P, Falanga C, Barillari MR, 
Cammaroto G, Khalife M, Leich P, Souchay C, Rossi C, Journe F, Hsieh J, Edjlali M, Carlier R, Ris L, Lovato A, De Filippis C, Coppee F, Fakhry N, Ayad T, Saussez S. Olfactory and gustatory dysfunctions as a clinical presentation of mild-to-moderate forms of the coronavirus disease (COVID-19): a multicenter European study. Eur Arch Otorhinolaryngol. 2020; 277: 2251-2261. [CrossRef]

[41] Shepherd GM. Smell images and the flavour system in the human brain. Nature. 2006; 444: 316-321. [CrossRef]

[42] Green BG. Chemesthesis and the chemical senses as components of a "chemofensor complex." Chem Senses. 2012; 37: 201-206. [CrossRef]

[43] Parma V, Ohla K, Veldhuizen MG, Niv MY, Kelly CE, Bakke AJ, Cooper KW, Bouysset C, Pirastu N, Dibattista M, Kaur R, Liuzza MT, Pepino MY, Schöpf V, Pereda-Loth V, Olsson SB, Gerkin RC, Domínguez PR, Albayay J, Farruggia MC, Bhutani S, Fjaeldstad AW, Kumar R, Menini A, Bensafi B, Sandell M, Konstantinidis Iordanis, Di Pizio A, Genovese F, Öztürk L, Thomas-DanguinT, Frasnelli J, Boesveldt S, Saatci Ö, Saraiva LR, Lin C, Golebiowski J, Hwang L-D, Ozdener MH, Guàrdia MD, Laudamiel C, Ritchie M, Havlícek J, Pierron D, Roura E, Navarro M, Nolden AA, Lim J, Whitcroft KL, Colquitt LR, Ferdenzi C, Brindha EV, Altundag A, Macchi A, Nunez-Parra A, Patel ZM, Fiorucci S, Philpott CM, Smith BC, Lundström JN, Mucignat C, Parker KJ, van den Brink M, Schmuker M, Fischmeister FPhS, Heinbockel T, Shields VDC, Faraji F, Santamaría E, Fredborg WEA, Morini G, Olofsson JK, Jalessi M, Karni N, D'Errico A, Alizadeh R, Pellegrino R, Meyer P, Huart C, Chen B, Soler GM, Alwashahi MK, WelgeLüssen A, Freiherr J, de Groot JHB, Klein H, Okamoto M, Singh PB, Hsieh JW, GCCR Group Author; Reed DR, Hummel T, Munger SD, Hayes JE. More than smell-COVID-19 is associated with severe impairment of smell, taste, and chemesthesis. Chem Senses. 2020; 45: 609-622. [CrossRef]

[44] Ellul MA, Benjamin L, Singh B, Lant S, Michael BD, Easton A, Kneen R, Defres S, Sejvar J, Solomon T. Neurological associations of COVID-19. Lancet Neurol. 2020; 19: 767-783. [CrossRef]

[45] Slooter AJC, Otte WM, Devlin JW, Arora RC, Bleck TP, Claassen J, Duprey MS, Ely EW, Kaplan PW, Latronico N, Morandi A, Neufeld KJ, Sharshar T, MacLullich AMJ, Stevens RD. Updated nomenclature of delirium and acute encephalopathy: statement of ten Societies. Intensive Care Med. 2020; 46: 1020-1022. [CrossRef]

[46] Dixon L, Varley J, Gontsarova A, Mallon D, Tona F, Muir D, Luqmani A, Jenkins IH, Nicholas R, Jones B, Everitt A. COVID-19-related acute necrotizing encephalopathy with brain stem involvement in a patient with aplastic anemia. Neurol Neuroimmunol Neuroinflamm. 2020; 7(5):e789. [CrossRef]

[47] Collantes MEV, Espiritu AI, Sy MCC, Anlacan VMM, Jamora RDG. Neurological manifestations in COVID-19 infection: A systematic review and meta-analysis. Can J Neurol Sci. 2021; 48: 66-76. [CrossRef]

[48] Avula A, Nalleballe K, Narula N, Sapozhnikov S, Dandu V, Toom S, Glaser A, Elsayegh D. Covid-19 presenting as stroke. Brain Behav Immun. 2020; 87: 115-119. [CrossRef]

[49] Al Saiegh F, Ghosh R, Leibold A, Avery MB, Schmidt RF, Theofanis T, Mouchtouris N, Philipp L, Peiper SC, Wang ZX, Rincon F, Tjoumakaris SI, Jabbour P, Rosenwasser RH, Gooch MR. Status of SARS-CoV-2 in cerebrospinal fluid of patients with COVID-19 and stroke. J Neurol Neurosurg Psychiatry. 2020; 91: 846-848. [CrossRef]

[50] Qiu F, Wu Y, Zhang A, Xie G, Cao H, Du M, Jiang H, Li S, Ding M. Changes of coagulation function and risk of stroke in patients with Covid-19. Brain Behav. 2021; 11(6): e02185. [CrossRef]

[51] Orsucci D, Ienco EC, Nocita G, Napolitano A, Vista M. Neurological features of COVID-19 and their treatment: a review. Drugs Context. 2020; 9: 2020-5-1. [CrossRef]

[52] Aggarwal G, Lippi G, Michael Henry B. Cerebrovascular disease is associated with an increased disease severity in patients with Coronavirus Disease 2019 (COVID-19): A pooled analysis of published literature. Int J Stroke. 2020; 15: 385-389. [CrossRef]

[53] Rábano-Suárez P, Bermejo-Guerrero L, Méndez-Guerrero A, Parra-Serrano J, Toledo-Alfocea D, Sánchez-Tejerina D, Santos-Fernández T, Folgueira-López MD, Gutiérrez-Gutiérrez J, Ayuso-García B, González de la Aleja J, BenitoLeón J. Generalized myoclonus in COVID-19. Neurology. 2020; 95(6): e767-e772. [CrossRef]

[54] Zimmermann KM, Harmel J, Wojtecki L. CORE-myoclonus syndrome: A proposed neurological initial manifestation of Covid-19. Mov Disord Clin Pract. 2021; 8: 637-638. [CrossRef]

[55] Vollono C, Rollo E, Romozzi M, Frisullo G, Servidei S, Borghetti A, Calabresi P. Focal status epilepticus as unique clinical feature of COVID-19: A case report. Seizure. 2020; 78: 109-112. [CrossRef]

[56] Fasano A, Cavallieri F, Canali E, Valzania F. First motor seizure as presenting symptom of SARS-CoV-2 infection. Neurol Sci. 2020; 41: 1651-1653. [CrossRef]

[57] Balloy G, Leclair-Visonneau L, Péréon Y, Magot A, Peyre A, Mahé PJ, Derkinderen P. Non-lesional status epilepticus in a patient with coronavirus disease 2019. Clin Neurophysiol. 2020; 131: 2059-2061. [CrossRef] 
[58] Somani S, Pati S, Gaston T, Chitlangia A, Agnihotri S. De Novo status epilepticus in patients with COVID-19. Ann Clin Transl Neurol. 2020; 7: 1240-1244. [CrossRef]

[59] Mahammedi A, Saba L, Vagal A, Leali M, Rossi A, Gaskill M, Sengupta S, Zhang B, Carriero A, Bachir S, Crivelli P, Paschè A, Premi E, Padovani A, Gasparotti R. Imaging of neurologic disease in hospitalized patients with COVID19: An Italian multicenter retrospective observational study. Radiology. 2020; 297(2): E270-E273. [CrossRef]

[60] Cheli M, Dinoto A, Olivo S, Tomaselli M, Stokelj D, Cominotto F, Brigo F, Manganotti P. Sars-Cov-2 pandemic and epilepsy: The impact on emergency department attendances for seizures. Seizure: Eur J Epilepsy. 2020; 82: 23-26. [CrossRef]

[61] Wang S-C, Su P-K, Pariante CM. The three frontlines against Covid-19: Brain Behav Immun. 2021; 93: $409-414$. [CrossRef]

[62] Borges do Nascimento IJ, Cacic N, Abdulazeem HM, von Groote TC, Jayarajah U, Weerasekara I, Esfahani MA, Civile VT, Marusic A, Jeroncic A, Carvas Junior N, Pericic TP, Zakarija-Grkovic I, Meirelles Guimarães SM, Luigi Bragazzi N, Bjorklund M, Sofi-Mahmudi A, Altujjar M, Tian M, Arcani DMC, O'Mathúna DP, Marcolino MS. Novel Coronavirus infection (COVID-19) in humans: A scoping review and meta-analysis. J Clin Med. 2020; 9 (4): 941. [CrossRef]

[63] Mao L, Jin H, Wang M, Hu Y, Chen S, He Q, Chang J, Hong C, Zhou Y, Wang D, Miao X, Li Y, Hu B. Neurologic manifestations of hospitalized patients with Coronavirus disease 2019 in Wuhan, China. JAMA Neurol. 2020; 77: 683690. [CrossRef]

[64] Gentile E, Delussi M, Abagnale C, Caponnetto V, De Cesaris F, Frattale I, Guaschino E, Marcinnò A, Ornello R, Pistoia F, Putortì A, Candida G, Roveta F, Lupi C, Coppola G, Prudenzano AMP, Rainero I, Sances G, Roca ME, Trojano M, Pierelli F, Geppetti P, Sacco S, de Tommaso M. Migraine during COVID-19: Data from Second Wave Pandemic in an Italian Cohort. Brain Sci. 2021; 11(4): 482. [CrossRef]

[65] Suzuki K, Takeshima T, Igarashi H, Imai N, Danno D, Yamamoto T, Nagata E, Haruyama Y, Mitsufuji T, Suzuki S, Ito Y, Shibata M, Kowa H, Kikui S, Shiina T, Okamura M, Tatsumoto M, Hirata K. Impact of the COVID-19 pandemic on migraine in Japan: a multicentre cross-sectional study. J Headache Pain. 2021; 22(1): 53. [CrossRef]

[66] Kajani R, Apramian A, Vega A, Ubhayakar N, Xu P, Liu A. Neuroleptic malignant syndrome in a COVID-19 patient. Brain Behav Immun. 2020; 88: 28-29. [CrossRef]

[67] Munz M, Wessendorf S, Koretsis G, Tewald F, Baegi R, Krämer S, Geissler M, Reinhard M. Acute transverse myelitis after COVID-19 pneumonia. J Neurol. 2020; 267: 2196-2197. [CrossRef]

[68] Boziki MK, Mentis AA, Shumilina M, Makshakov G, Evdoshenko E, Grigoriadis N. COVID-19 immunopathology and the central nervous system: Implication for multiple sclerosis and other autoimmune diseases with associated demyelination. Brain Sci. 2020; 10(6): 345. [CrossRef]

[69] d'Orsi G, Sica S, Maiorano A, Melchionda D, Lalla A, Montemurro L, Sabetta A, Goffredo R, Lecce B, Fiore JR, Santantonio T, Avolio C. Guillain-Barre syndrome as only manifestation of COVID-19 infection. Clin Neurol Neurosurg. 2021; 207: 106775. [CrossRef]

[70] Finsterer J, Scorza FA, Scorza CA, Fiorini AC. Attributing increased prevalence of facial palsy to SARS-CoV-2 requires evidence. Brain Behav. 2021; 11(2): e01996. [CrossRef]

[71] Almeira M, Cejudo JC, Sotoca J, Deus J, Krupinski J. Cognitive profile following Covid-19 infection: Clinical predictors leading to neuropsychological impairment. Brain Behav Immun Health. 2020; 9: 100163. [CrossRef]

[72] Hosseini S, Wilk E, Michaelsen-Preusse K, Gerhauser I, Baumgärtner W, Geffers R, Schughart K, Korte M. Long-term neuroinflammation induced by influenza A virus infection and the impact on hippocampal neuron morphology and function. J Neurosci. 2018; 38: 3060-3080. [CrossRef]

[73] Sher L. Post-Covid syndrome and suicide risk. QJM. 2021; 114: 95-98. [CrossRef]

[74] Carod-Artal FJ. Post-COVID-19 syndrome: epidemiology, diagnostic criteria and pathogenic mechanisms involved. Rev Neurol. 2021; 72: 384-396. [CrossRef]

[75] Yong SJ. Long COVID or post-COVID-19 syndrome: putative pathophysiology, risk factors, and treatments. Infect Dis. 2021; May 22: 1-18 (doi: 10.1080/23744235.2021.1924397). [CrossRef]

[76] Salamanna F, Veronesi F, Martini L, Landini MP, Fini M. Post-COVID-19 syndrome: The persistent symptoms at the post-viral stage of the disease. A systematic review of the current data. Front Med. 2021; 8: 653516. [CrossRef]

[77] Kennedy M, Helfand BKI, Gou RY, Gartaganis SL, Webb M, Moccia JM, Bruursema SN, Dokic B, McCulloch B, Ring H, Margolin JD, Zhang E, Anderson R, Babine RL, Hshieh T, Wong AH, Taylor RA, Davenport K, Teresi B, Fong TG, 
Inouye SK. Delirium in older patients with COVID-19 presenting to the emergency department. JAMA Netw Open. 2020; 3(11): e2029540. [CrossRef]

[78] LaHue SC, James TC, Newman JC, Esmaili AM, Ormseth CH, Ely EW. Collaborative delirium prevention in the age of COVID-19. J Am Geriatr Soc. 2020; 68: 947-949. [CrossRef]

[79] Teimouri-Jervekani Z, Salmasi M. Presentation of Covid-19 infection with bizarre behavior and encephalopathy: A case report. J Med Case Reports. 2021; 15: 220. [CrossRef]

[80] Rogers JP, Chesney E, Oliver D, Pollak TA, McGuire P, Fusar-Poli P, Zandi MS, Lewis G, David AS. Psychiatric and neuropsychiatric presentations associated with severe coronavirus infections: a systematic review and meta-analysis with comparison to the COVID-19 pandemic. Lancet Psychiatry. 2020; 7: 611-627. [CrossRef]

[81] Vanderlind WM, Rabinovitz BB, Miao IY, Oberlin LE, Bueno-Castellano C, Fridman C, Jaywant A, Kanellopoulos D. A systematic review of neuropsychological and psychiatric sequalae of COVID-19: implications for treatment. Curr Opin Psychiatry. 2021; 34: 420-433. [CrossRef]

[82] Koprdova R, Bögi E, Belovičová K, Sedláčková N, Okuliarová M, Ujházy E, Mach M. Chronic unpredictable mild stress paradigm in male Wistar rats: effect on anxiety- and depressive-like behavior. Neuro Endocrinol Lett. 2016; 37(Suppl1): 103-110. [CrossRef]

[83] Fiksdal A, Hanlin L, Kuras Y, Gianferante D, Chen X, Thoma MV, Rohleder N. Associations between symptoms of depression and anxiety and cortisol responses to and recovery from acute stress. Psychoneuroendocrinology. 2019; 102: 44-52. [CrossRef]

[84] Murthy P, Narasimha VL. Effects of the COVID-19 pandemic and lockdown on alcohol use disorders and complications. Curr Opin Psychiatry. 2021; 34: 376-385. [CrossRef]

[85] Manthey J, Kilian C, Carr S, Bartak M, Bloomfield K, Braddick F, Gual A, Neufeld M, O'Donnell A, Petruzelka B, Rogalewicz V, Rossow I, Schulte B, Rehm J. Use of alcohol, tobacco, cannabis, and other substances during the first wave of the SARS-CoV-2 pandemic in Europe: a survey on 36,000 European substance users. Subst Abuse Treat Prev Policy. 2021; 16(1): 36. [CrossRef]

[86] MacMillan T, Corrigan MJ, Coffey K, Tronnier CD, Wang D, Krase K. Exploring factors associated with alcohol and/or substance use during the COVID-19 Pandemic. Int J Ment Health Addict. 2021; Jan 26: 1-10. [CrossRef]

[87] Valdés-Florido MJ, López-Díaz Á, Palermo-Zeballos FJ, Garrido-Torres N, Álvarez-Gil P, Martínez-Molina I, MartínGil VE, Ruiz-Ruiz E, Mota-Molina M, Algarín-Moriana MP, Guzmán-Del Castillo AH, Ruiz-Arcos Á, GómezCoronado R, Galiano-Rus S, Rosa-Ruiz A, Prados-Ojeda JL, Gutierrez-Rojas L, Crespo-Facorro B, Ruiz-Veguilla M. Clinical characterization of brief psychotic disorders triggered by the COVID-19 pandemic: a multicenter observational study. Eur Arch Psychiatry Clin Neurosci. 2021; 3: 1-11. [CrossRef]

[88] Chacko M, Job A, Caston F 3rd, George P, Yacoub A, Cáceda R. COVID-19-Induced Psychosis and Suicidal Behavior: Case Report. SN Compr Clin Med. 2020; 26: 1-5. [CrossRef]

[89] Gillett G, Jordan I. Severe psychiatric disturbance and attempted suicide in a patient with COVID-19 and no psychiatric history. BMJ Case Rep. 2020; 13(10): e239191. [CrossRef]

[90] Habu H, Takao S, Fujimoto R, Naito H, Nakao A, Yorifuji T. Emergency dispatches for suicide attempts during the COVID-19 outbreak in Okayama, Japan: A descriptive epidemiological study. J Epidemiol. 2021 Jun 26 (doi: 10.2188/jea.JE20210066). [CrossRef]

[91] Panda PK, Gupta J, Chowdhury SR, Kumar R, Meena AK, Madaan P, Sharawat IK, Gulati S. Psychological and behavioral impact of lockdown and quarantine measures for COVID-19 pandemic on children, adolescents and caregivers: A systematic review and meta-analysis. J Trop Pediatr. 2021; 67(1): fmaa122. [CrossRef]

[92] Shah R, Raju VV, Sharma A, Grover S. Impact of COVID-19 and lockdown on children with ADHD and their familiesan online survey and a continuity care model. J Neurosci Rural Pract. 2021; 12: 71-79. [CrossRef]

[93] Ueda R, Okada T, Kita Y, Ozawa Y, Inoue H, Shioda M, Kono Y, Kono C, Nakamura Y, Amemiya K, Ito A, Sugiura N, Matsuoka Y, Kaiga C, Kubota M, Ozawa H. The quality of life of children with neurodevelopmental disorders and their parents during the Coronavirus disease 19 emergency in Japan. Sci Rep. 2021; 11(1): 3042. [CrossRef]

[94] Bruni O, Giallonardo M, Sacco R, Ferri R, Melegari MG. The impact of lockdown on sleep patterns of children and adolescents with ADHD. J Clin Sleep Med. 2021 Apr 1 (doi: 10.5664/jcsm.9296). [CrossRef]

[95] Shorey S, Lau LST, Tan JX, Ng ED, Ramkumar A. Families with children with neurodevelopmental disorders during COVID-19: A scoping review. 2021; 46(5): 514-525. [CrossRef] 
[96] Fox KR, Stathi A, McKenna J, Davis MG. Physical activity and mental well-being in older people participating in the Better Ageing Project. Eur J Appl Physiol. 2007; 100: 591-602. [CrossRef]

[97] Cunningham C, O' Sullivan R, Caserotti P, Tully MA. Consequences of physical inactivity in older adults: A systematic review of reviews and meta-analyses. Scand J Med Sci Sports. 2020; 30: 816-827. [CrossRef]

[98] Cohen G, Russo MJ, Campos JA, Allegri RF. COVID-19 epidemic in Argentina: Worsening of behavioral symptoms in elderly subjects with dementia living in the community. Front Psychiatry. 2020; 11: 866. [CrossRef]

[99] Shea YF, Shum CK, Wan WH, Chan MMK. Worsening behavioural and psychological symptoms of dementia during the coronavirus disease 2019 pandemic. Psychogeriatrics. 2020; 20: 916-917. [CrossRef]

[100] Xia X, Wang Y, Zheng J. COVID-19 and Alzheimer's disease: how one crisis worsens the other. Transl Neurodegener. 2021; 10(1): 15. [CrossRef]

[101] Cohen G, Russo MJ, Campos JA, Allegri RF. Living with dementia: increased level of caregiver stress in times of COVID-19. Int Psychogeriatr. 2020; 32: 1377-1381. [CrossRef]

[102] Borelli WV, Augustin MC, de Oliveira PBF, Reggiani LC, Bandeira-de-Mello RG, Schumacher-Schuh AF, Chaves MLF, Castilhos RM. Neuropsychiatric symptoms in patients with dementia associated with increased psychological distress in caregivers during the COVID-19 pandemic. J Alzheimers Dis. 2021; 80: 1705-1712. [CrossRef]

[103] Gillespie SM, Wasserman EB, Wood N, Wang H, Dozier A, Nelson D, McConnochie KM, Shah MN. High-intensity telemedicine reduces emergency department use by older adults with dementia in senior living communities. J Am Med Dir Assoc. 2019; 20: 942-946. [CrossRef]

[104] Geddes MR, O'Connell ME, Fisk JD, Gauthier S, Camicioli R, Ismail Z; Alzheimer Society of Canada Task Force on Dementia Care Best Practices for COVID-19. Remote cognitive and behavioral assessment: Report of the Alzheimer Society of Canada Task Force on dementia care best practices for COVID-19. Alzheimers Dement. 2020; 12 (1): e12111. [CrossRef]

[105] Lombart M, Pastoret PP, Moulin AM. A brief history of vaccines and vaccination. Rev Sci Tech. 2007; $26: 29-48$. [CrossRef]

[106] Cheng H, Peng Z, Luo W, Si S, Mo M, Zhou H, Xin X, Liu H, Yu Y. Efficacy and safety of COVID-19 vaccines in phase III trials: A meta-analysis. Vaccines. 2021; 9(6): 582. [CrossRef]

[107] Xu S, Yang K, Li R, Zhang L. mRNA vaccine era-mechanisms, drug platform and clinical prospection. Int J Mol Sci. 2020; 21(18): 6582. [CrossRef]

[108] Pascolo S. Synthetic messenger RNA-based vaccines: from scorn to hype. Viruses. 2021; 13(2): 270. [CrossRef]

[109] Anand P, Stahel VP. The safety of Covid-19 mRNA vaccines: a review. Patient Saf Surg. 2021; 15: 22. [CrossRef]

[110] Finsterer J, Scorza FA. SARS-CoV-2 vaccines are not free of neurological side effects. Acta Neurol Scand. 2021; 144: 109-110. [CrossRef]

[111] Aladdin Y, Shirah B. New-onset refractory status epilepticus following the ChAdOx1 nCoV-19 vaccine. J Neuroimmunol. 2021; 357: 577629. [CrossRef]

[112] Keir G, Maria NI, Kirsch CFE. Unique Imaging Findings of Neurologic Phantosmia Following Pfizer-BioNtech COVID-19 Vaccination: A Case Report. Top Magn Reson Imaging. 2021; 30: 133-137. [CrossRef]

[113] Lu L, Xiong W, Mu J, Zhang Q, Zhang H, Zou L, Li W, He L, Sander JW, Zhou D. Neurological side effects of COVID19 vaccines are rare. Acta Neurol Scand. 2021; 144: 111-112. [CrossRef]

[114] Khan S, Siddique R, Xiaoyan W, Zhang R, Nabi G, Sohail Afzal M, Liu J, Xue M. Mental health consequences of infections by coronaviruses including severe acute respiratory syndrome coronavirus 2 (SARS-CoV-2). Brain Behav. 2021; 11(2): e01901. [CrossRef]

[115] Yolken RH, Torrey EF. Are some cases of psychosis caused by microbial agents? A review of the evidence. Mol Psychiatry. 2008; 13: 470-479. [CrossRef]

[116] van den Pol AN. Viral infection leading brain dysfunction: more prevalent than appreciated? Neuron. 2009; 64: 1720. [CrossRef]

[117] Sutterland AL, Fond G, Kuin A, Koeter MW, Lutter R, van Gool T, Yolken R, Szoke A, Leboyer M, de Haan L. Beyond the association. Toxoplasma gondii in schizophrenia, bipolar disorder, and addiction: systematic review and metaanalysis. Acta Psychiatr Scand. 2015; 132: 161-179. [CrossRef]

This is an open access article which is publicly available on our journal's website under Institutional Repository at http://dspace.marmara.edu.tr. 